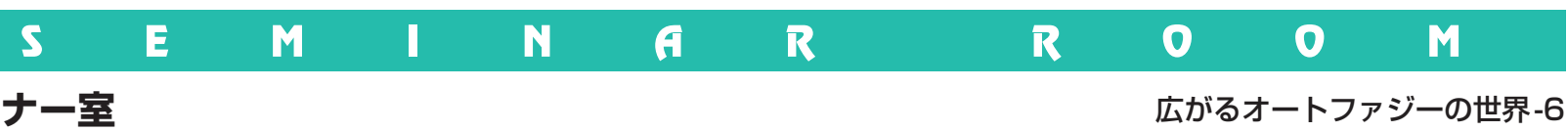

\title{
糸状菌のオートファジーと物質生産
}

\section{菊間隆志, 北本勝ひこ}

東京大学大学院農学生命科学研究科
はじめに

糸状菌はその名のとおり細長い糸状の細胞（菌糸）を 伸長させ増殖する多細胞真核微生物であり, その種は 150万を超えると考えられている，その中には，ヒトや 家畜，農作物に対して病原性を示すものが存在する一 方，食品製造や医薬品製造に利用される有益なものも多 く存在する。このような糸状菌の性質は, 種の多様性に 加え，高度な極性をもった菌系抢よび環境変化に伴う分 化といった形態的特徵が密接に関連している．たとえ ば，極性生長を続けているときは，細長い菌系の先端か ら多量の酵素を分泌し，また環境ストレスに応答して無 性胞子（分生子）もしくは有性胞子を形成する．植物病 原性糸状菌では宿主への感染時には付着器や侵入菌糸を 形成する.このような特徵は, さまざまな細胞内の機構 によって制御されているが, その一つとしてオートファ ジーが重要な役割を担っていることが近年明らかとなっ てきた.

今回, 清酒, 味噌, 槒油などの醸造に古くから使用さ れており，わが国の国菌（http://www.jozo.or.jp/koujikinnituite2.pdf\#search=趜菌+国菌）である匐菌Asper gillus oryzaeを中心として, 糸状菌におけるオートファ ジーの生理機能について, また植物病原性糸状菌の感染 時に抢けるオートファジーの機能について解説する.さ らに, オートファジー制御が糸状菌による有用物質生産
のアプローチの一つとなりうることを示した最近の研究 を紹介する。

\section{糸状菌におけるオートファジー関連遺伝子}

糸状菌のオートファジーに関しては, Podospora anserinaの不和合性の研究が始まりと言える. 2003年に P. anserinaにおける不和合性の研究で, 不和合性によ る細胞死の期間にオートファジーが誘導されることが示 唆されたことから, ATG8のホモログとしてidi-7 (後 のPaATG8) が単離され，不和合性によるidi-7の発現 上昇抢よびオートファジーの誘導が観察された ${ }^{(1)}$ 。ま た，2005年にPaATG1が単離され，PaATG1 破壊株お よびPaATG8破壊株では不和合性による細胞死が促進 されることから，オートファジーがこの細胞死に対して 防御的に機能しているという報告がなされた ${ }^{(2)}$.ほかの 糸状菌では, 2006年にA. oryae ${ }^{(3)}$ およびMagnaporthe grisea $^{(4)}$ (現在ではMagnaporthe oryzae と改名されてい る) でATG8のホモログ遺伝子の解析が行われた。 そ の後, さまざまな糸状菌のゲノム解読が完了し, この 8 年間で多くのオートファジー関連遺伝子の解析が進めら れるようになった。これまでに解析された糸状菌のオー トファジー関連遺伝子 $(A T G$ 遺伝子) を表1に示した。 鳌菌 $A$. oryzaeをはじめとして, 植物病原性糸状菌（M. oryzae, Colletotrichum orbiculareなど), 最近では昆虫 
表 1 ・糸状菌におけるオートファジー関連遺伝子

\begin{tabular}{|c|c|c|c|c|}
\hline $\begin{array}{l}\text { 酵母 } A T G \\
\text { 遺伝子 }\end{array}$ & コードするタンパク質の機能 & オルソログ & 破壊株の表現型 & 文献 \\
\hline \multirow[t]{8}{*}{$A T G 1$} & $\begin{array}{l}\text { オートファジーを誘導する Ser/Thr } \\
\text { タンパク質キナーゼ }\end{array}$ & $\begin{array}{l}\text { Podospora anserina } \\
\text { PaATG1 }\end{array}$ & $\begin{array}{l}\text { 原子囊殼形成低下, 菌糸の色素沈着低下, } \\
\text { 不和合性による細胞死促進 }\end{array}$ & 2 \\
\hline & & $\begin{array}{l}\text { Aspergillus fumigatus } \\
\text { Afatg1 }\end{array}$ & 分生子形成低下，異常な分生子柄の形成 & 19 \\
\hline & & $\begin{array}{l}\text { Magnaporthe oryzae } \\
\text { Moatg1 }\end{array}$ & $\begin{array}{l}\text { 感染能㳖失, 分生子の脂肪滴隇少, 付着器 } \\
\text { の膨圧低下 }\end{array}$ & $14,25,26$ \\
\hline & & $\begin{array}{l}\text { Neurospora crassa } \\
\text { apg-1 }\end{array}$ & $\begin{array}{l}\text { 有性および無性生殖低下, メナジオンとペ } \\
\text { ルオキシド感受性 }\end{array}$ & 27 \\
\hline & & $\begin{array}{l}\text { Penicillium chrysoge- } \\
\text { num atg1 }\end{array}$ & 分生子形成低下, ペニシリン生産増加 & 21 \\
\hline & & $\begin{array}{l}\text { Metarhizium robertsii } \\
\text { MrATG1 }\end{array}$ & $\begin{array}{l}\text { 分生子形成低下, 感染能低下（付着器は形 } \\
\text { 成), 脂肪滴の蓄積低下 }\end{array}$ & 28 \\
\hline & & Aspergillus niger atg1 & $\begin{array}{l}\text { 分生子形成低下, メナジオン耐性, 過酸化 } \\
\text { 水素感受性 }\end{array}$ & 29 \\
\hline & & $\begin{array}{l}\text { Aspergillus oryzae } \\
\text { Aoatg1 }\end{array}$ & 気中菌糸と分生子形成低下 & 6 \\
\hline ATG2 & Atg2-Atg18複合体を形成 & M. oryzae Moatg2 & $\begin{array}{l}\text { 感染能喪失, 分生子形成低下, 付着器形成 } \\
\text { 低下 }\end{array}$ & 25,30 \\
\hline ATG3 & PEをAtg8に結合させるE2様酵素 & M. oryzae Moatg $3^{*}$ & 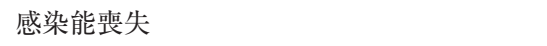 & 25 \\
\hline \multirow[t]{4}{*}{$A T G 4$} & $\begin{array}{l}\text { Atg8をプロセシングするシステイン } \\
\text { プロテアーゼ }\end{array}$ & M. oryzae Moatg4 & $\begin{array}{l}\text { 感染能言失, 子囊殼形成低下, 気中菌系と } \\
\text { 分生子形成低下, 発芽遅延 }\end{array}$ & $11,31,25$ \\
\hline & & A. oryzae Aoatg4 & 気中菌糸と分生子形成低下 & 5 \\
\hline & & M. robertsii MrATG4 & $\begin{array}{l}\text { 分生子柄形成低下, 感染能低下（付着器は } \\
\text { 形成), 脂肪滴の蓄積低下 }\end{array}$ & 28 \\
\hline & & $\begin{array}{l}\text { Sordaria macrospora } \\
\text { Smatg4 }\end{array}$ & 子実体形成低下，胞子発芽率低下 & 32 \\
\hline \multirow[t]{3}{*}{ ATG5 } & Atg12-Atg5 複合体を形成 & M. oryzae Moatg5 & $\begin{array}{l}\text { 感染能䘫失, 子囊殼形成低下, 気中菌糸と } \\
\text { 分生子形成低下, 発芽遅延 }\end{array}$ & 25,33 \\
\hline & & $\begin{array}{l}\text { Trichoderma reesei } \\
\text { TrATG5 }\end{array}$ & 分生子形成低下，異常な分生子柄の形成 & 34 \\
\hline & & $\begin{array}{l}\text { Beauveria bassiana } \\
\text { BbATG5 }\end{array}$ & 分生子発芽率低下, 分生子形成低下 & 35 \\
\hline ATG6 & PtdIns3キナーゼ複合体を形成 & M. oryzae Moatg6* & 感染能䘫失 & 25 \\
\hline \multirow[t]{2}{*}{$A T G 7$} & Atg12 と Atg8 を活性化する E1 様酵素 & M. oryzae Moatg $7^{*}$ & 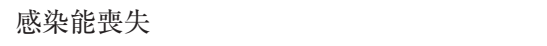 & 25 \\
\hline & & S. macrospora Smatg7 & $\begin{array}{l}\text { 生育に必須, ノックダウンで子実体形成異 } \\
\text { 常 }\end{array}$ & 36 \\
\hline \multirow[t]{8}{*}{$A T G 8$} & $\begin{array}{l}\mathrm{PE} \text { と結合するユビキチン様タンパク } \\
\text { 質 }\end{array}$ & $\begin{array}{l}\text { P. anserina PaATG8 } \\
(\text { idi-7) }\end{array}$ & $\begin{array}{l}\text { 原子囊殼形成低下, 菌糸の色素沈着低下, } \\
\text { 不和合性による細胞死促進 }\end{array}$ & 1 \\
\hline & & A. oryzae Aoatg8 & $\begin{array}{l}\text { 気中菌糸と分生子形成低下, 分生子発芽遅 } \\
\text { 延 (条件発現株) }\end{array}$ & 3 \\
\hline & & $\begin{array}{l}\text { Colletotrichum orbicu- } \\
\text { lare CoATG8 }\end{array}$ & $\begin{array}{l}\text { 分生子形成低下, 分生子発芽率低下, 付着 } \\
\text { 器形成低下, 感染能言失 }\end{array}$ & 17 \\
\hline & & M. oryzae Moatg8 & 感染能喪失, 分生子形成低下 & $\begin{array}{c}4,25,30, \\
37\end{array}$ \\
\hline & & $\begin{array}{l}\text { Fusarium gra- } \\
\text { minearum Fgatg8 }\end{array}$ & $\begin{array}{l}\text { 子囊喨形成低下, 分生子と気中菌糸形成低 } \\
\text { 下 }\end{array}$ & 38 \\
\hline & & $\begin{array}{l}\text { Arthrobotrys oligospora } \\
\text { atg8 }\end{array}$ & トラップ器形成低下，感染能低下 & 39 \\
\hline & & A. niger atg8 & $\begin{array}{l}\text { 分生子形成低下, メナジオン耐性, 過酸化 } \\
\text { 水素感受性 }\end{array}$ & 29 \\
\hline & & M. robertsii $M r A T G 8$ & $\begin{array}{l}\text { 分生子形成低下, 付着器形成低下, 感染能 } \\
\text { 低下, 脂肪滴の蓄積低下 }\end{array}$ & 28 \\
\hline ATG9 & $\begin{array}{l}\text { Atg11や Atg17 と相互作用する膜貫通 } \\
\text { タンパク質 }\end{array}$ & $\begin{array}{l}\text { S. macrospora Smatg } 8 \\
\text { M. oryzae Moatg9 }\end{array}$ & $\begin{array}{l}\text { 子実体形成低下, 胞子発芽率低下 } \\
\text { 感染能䘫失, 分生子形成低下, 付着器形成 } \\
\text { 低下 }\end{array}$ & $\begin{array}{c}32 \\
25,30\end{array}$ \\
\hline ATG10 & $\begin{array}{l}\text { Atg12 と Atg5 を結合するする E2 様酵 } \\
\text { 素 }\end{array}$ & M. oryzae Moatg10* & 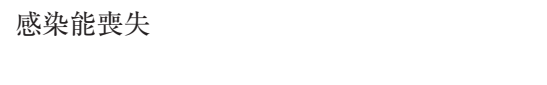 & 25 \\
\hline
\end{tabular}




\begin{tabular}{|c|c|c|c|c|}
\hline $\begin{array}{l}\text { 酵母 } A T G \\
\text { 遺伝子 }\end{array}$ & コードするタンパク質の機能 & オルソログ & 破壊株の表現型 & 文献 \\
\hline ATG11 & $\begin{array}{l}\text { 選択的オートファジーのアダプター } \\
\text { タンパク質 }\end{array}$ & M. oryzae Moatg11* & 顕著な表現型なし & 25 \\
\hline ATG12 & Atg12-Atg5複合体を形成 & M. oryzae Moatg12* & 感染能喪失 & 25 \\
\hline \multirow[t]{2}{*}{ ATG13 } & Atg1 キナーゼ複合体を形成 & M. oryzae Moatg13 & 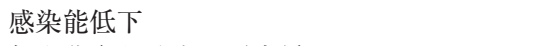 & 25,30 \\
\hline & & A. oryzae Aoatg13 & 気中菌系と分生子形成低下 & 5 \\
\hline \multirow[t]{4}{*}{ ATG15 } & $\begin{array}{l}\text { オートファジックボディーを分解す } \\
\text { るリパーゼ様酵素 }\end{array}$ & M. oryzae Moatg15* & 感染能言失 & 25 \\
\hline & & A. oryzae Aoatg15 & $\begin{array}{l}\text { 気中菌糸と分生子形成低下, 液胞でのオー } \\
\text { トファジックボディー蓄積 }\end{array}$ & 5 \\
\hline & & F. graminearum & $\begin{array}{l}\text { 感染能低下，気中菌糸と分生子形成低下， } \\
\text { 登芽率低下＼cjkstart脂啠分解低下 }\end{array}$ & 40 \\
\hline & & $\begin{array}{l}\text { Figatg15 } \\
\text { M. robertsii MrATG15 }\end{array}$ & $\begin{array}{l}\text { 発牙率低下, 脂質分解低下 } \\
\text { 感染能低下 (付着器は形成), 脂肪滴の蓄積 } \\
\text { 低下 }\end{array}$ & 28 \\
\hline ATG16 & Atg12-Atg5複合体の構成因子 & M. oryzae Moatg $16^{*}$ & 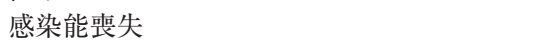 & 25 \\
\hline \multirow[t]{2}{*}{ ATG17 } & PAS形成の足場タンパク質 & M. oryzae Moatg17* & 感染能喪失 & 25 \\
\hline & & A. niger atg17 & 顕著な表現型なし & 29 \\
\hline ATG18 & PI(3)P 結合タンパク質 & M. oryzae Moatg18 & $\begin{array}{l}\text { 感染能低下, 分生子形成低下, 付着器形成 } \\
\text { 低下 }\end{array}$ & 25,30 \\
\hline ATG24 & $\begin{array}{l}\text { Cvt（cytoplasm-to-vacuole targeting） } \\
\text { 経路関連タンパク質 }\end{array}$ & M. oryzae Moatg24 & 気中菌系と分生子形成低下 & 25,41 \\
\hline \multirow[t]{2}{*}{ ATG26 } & ペキソファジー関連タンパク質 & M. oryzae Moatg $26^{*}$ & 顕著な表現型なし & 25 \\
\hline & & $\begin{array}{l}\text { C. orbiculare } \\
\text { CoATG } 26\end{array}$ & 感染能低下（付着器は形成） & 17 \\
\hline$A T G 27$ & Atg9 と結合する膜タンパク質 & M. oryzae Moatg $27^{*}$ & 顕著な表現型なし & 25 \\
\hline ATG28 & ペキソファジー関連タンパク質 & M. oryzae Moatg $28^{*}$ & 顕著な表現型なし & 25 \\
\hline ATG29 & Atg17 と結合 & M. oryzae Moatg29* & 顕著な表現型なし & 25 \\
\hline
\end{tabular}

*: M. oryzaeのゲノムワイドな解析によって病原性のみを検討したもの

病原性菌であるMetarhizium robertsii，線虫捕食菌の Arthrobotrys oligospora といったさまざまな糸状菌の オートファジーの解析が行われている.オートファジー 誘導の中心的な機能をもつキナーゼ遺伝子である $A T G 1$ ，オートファジーのマーカーとして利用されてい るATG8が多くの系状菌で解析されている．これらの 研究の結果, 糸状菌特異的なオートファジーの生理機能 が明らかになりつつある。

\section{麹菌 A. oryzaeの形態形成とオートファジー}

A. oryzae は，分生子から細長い細胞（菌糸）を伸長 させることにより生長する，寒天培地上では，培地表面 上を伸長する菌糸に加え，空中に向けて伸長する気中菌 糸を形成し, 気中菌糸の先端が膨潤し頂囊となりフィア ライドが形成され，そこから分生子が形成される（図 $1 \mathrm{~A})$.

筆者らはA. oryzaeにおいて, ほかの生物でもオート ファジーのマーカータンパク質として利用されている Atg8のホモログであるAoatg8遺伝子の機能を解析し た. 緑色蛍光タンパク質EGFP (enhanced green fluo- rescent protein）とAoAtg8の融合タンパク質を発現さ せることにより, PAS (preautophagosomal structure もしくは phagophore assembly site) 様の構造, 隔離 膜，オートファゴソーム，オートファジックボディーな どのオートファジー特異的な構造体を観察することがで きた ${ }^{(3,5)}$ 。また，窒素源飢餓条件下では，オートファ ジーが誘導され蛍光の液胞への蓄積が観察された（図 1B左).

A. oryzae は通常の培地から窒素源枯渇培地にシフト するとオートファジーが誘導されるが，筆者らは通常の 培地に扔いても, 頂囊を形成した気中菌系, 頂囊, フィ アライドでは液胞が発達し，オートファジーが起きてい ることを見いだした ${ }^{(3)}$ 。また，分生子を液体培地に植菌 すると始めの 4 時間ほどは，等方向に生長することによ り直径が 3 倍程度に膨潤し, その後, 極性生長により発 芽菅が生じる。この一連の発芽の過程においても液胞が 発達し，オートファジーの誘導が観察された ${ }^{(3)}$ 。これら は，発芽や分生子形成といった形態分化においてオート ファジーが重要な機能を担っていることを示唆してい る.そこで，オートファジー誘導に関与するAoatg1, Aoatg13，オートファゴソーム形成に必須なAoatg4, 
A

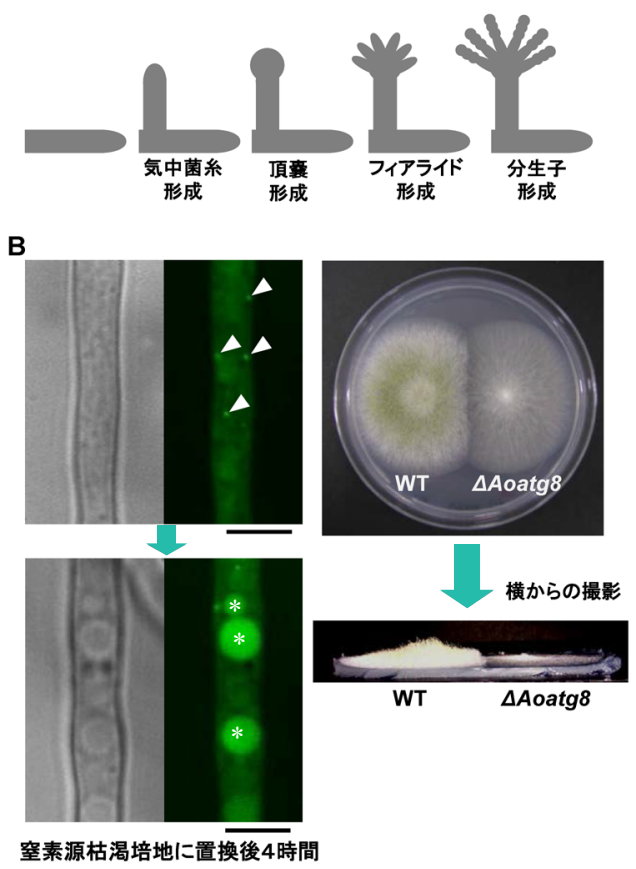

C

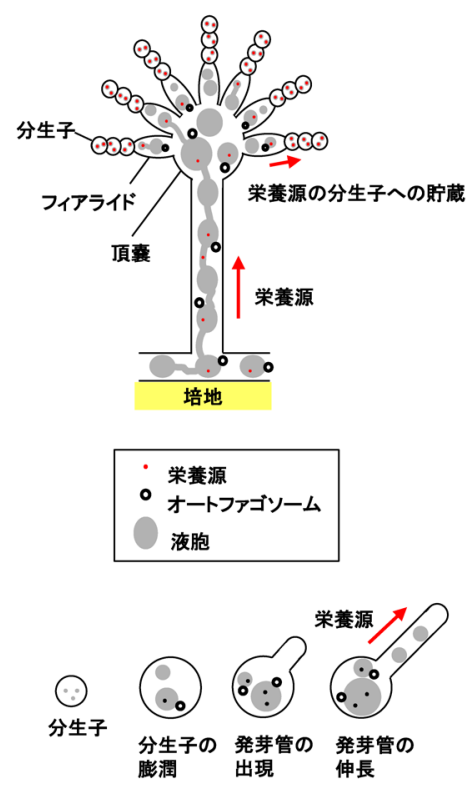

図 1-A. oryzaeの形態分化とオートファ ジー

A）A. oryzaeの分生子形成過程. 気中菌系 が形成されたのち, 頂囊, フィアライド, 分生子と順番に形成される。B）窒素源を 枯渇させると細胞質に存在していたEGFPAoAtg8の蛍光が液胞に蓄積する (左). A . oryzaeのオートファジー欠損株（ $\triangle$ A A oatg 8$)$ は気中菌系および分生子形成が顕著に抑制 される (右). 矢頭 : PAS. * : 液胞. ス ケールバーは $5 \mu \mathrm{m}$. 文献 3,5 から改変して 揭載. C) A. oryzaeにおける分生子形成時 および分生子発芽時のオートファジーの役 割のモデル. 文献7から改変して掲載.
Aoatg8, オートファジックボディーの分解に必須な Aoatg15の各遺伝子破壊株を作製し解析した。その結 果, 野生株では寒天培地上に生育したコロニーの色が緑 色で, 分生子の形成が確認されるが, これらの破壊株で はコロニーは白色であり，分生子の形成が顕著に低下す ることがわかった ${ }^{(3,5,6)}$. Aoatg8破壊株のコロニーを横 から見ると，気中菌系をほとんど形成していないことも 観察された（図1B右）。また，A. oryzaeは炭素源がな いと分生子は発芽しないが, 窒素源がなくても発芽する ことができる。窒素源枯渴培地において分生子の A oatg8の発現を抑制すると発芽の遅延が観察された ${ }^{(3)}$. 分生子形成のための気中菌系は, 培地から直接栄養源を 獲得することができない. そこで, 気中菌系や頂囊, フィアライドではオートファジーが誘導され， タンパク 質やオルガネラがリサイクルされることにより, 形態の 変化に伴う細胞の再構築が行われていると考えられる ${ }^{(7)}$ (図1C)。また，分生子からの発芽に関しては，発芽管 を形成し極性生長を行うまでの約 6 時間は，アミノ酸な どの栄養源を取り込むトランスポーターの発現が十分で ないこと, また, プロテアーゼなどの加水分解酵素の分 泌がされないことから, 外界から栄養源を獲得できない と推定される。すなわち, 外界から栄養を取り込めるよ うになるまでの限られた時間での栄養源獲得をオート ファジーに依存していると考えられる ${ }^{(7)}$ (図 $1 \mathrm{C}$ )。ほか の多くの糸状菌におけるオートファジー関連遺伝子破壊 株で, 気中菌糸形成, 分生子形成, 有性生殖器官形成な
どに影響が出ることからも（表1），オートファジーの 形態分化における重要性がうかがえる.

毒菌 A. oryzaeにおけるオートファジーによるオル ガネラの分解

A. oryzaeは一つの細胞に多数の核を有する多核細胞 からなる。また，菌系先端細胞は核や小胞体，ミトコン ドリアなどが多く存在し ${ }^{(8,9)}$, この先端細胞が伸長する ことによって生長する。一方, 菌系基部の古い細胞は液 胞が大部分を占め, 細胞の伸長などは見られない。筆者 らは, A. oryzaeにおいて分生子植菌後48時間培養した 基部の細胞においてペルオキシソーム，ミトコンドリア を観察したところ，これらのオルガネラが液胞に取り込 まれることを見いだした(10) (図2A)。また，異常タン パク質を蓄積した小胞体もオートファジー依存的に液胞 へ輸送されることが観察された ${ }^{(11)}$. Aoatg8破壊株では これらのオルガネラの液胞への取り込みは観察されない ことから, 不要になったオルガネラはオートファジーに よって液胞で分解されていると考えられる.これらのこ とより，A. oryzaeは菌系基部の細胞質成分をオート ファジーによって分解して栄養源としてリサイクルし, チューブ状の液胞を介して生長している菌系細胞に輸送 していると考えられる(12).

さらに興味深いことに，48時間培養後の菌系基部で 核が液胞内に取り达まれることを見いだした ${ }^{(10)}$ (図 2B)。核がどのように液胞へ輸送されるかを，隔離膜を 
A

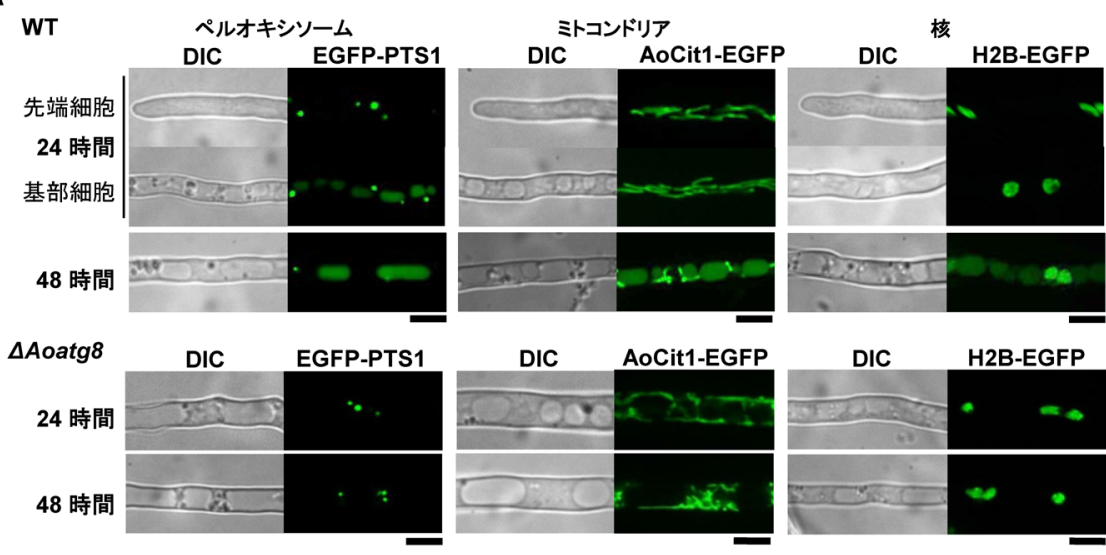

B

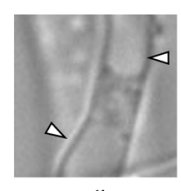

0 分

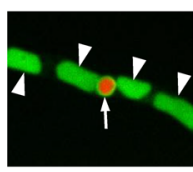

0 分

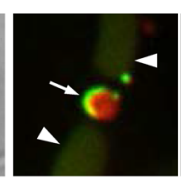

0 分

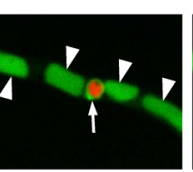

5 分

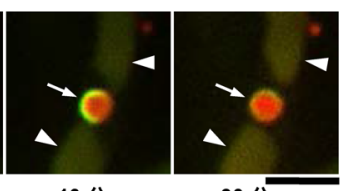

10 分

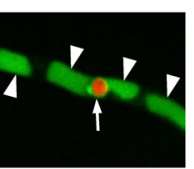

6 分

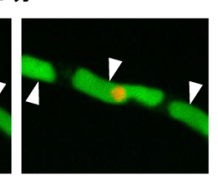

7 分

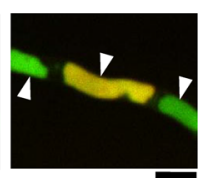

11 分
図2・A. oryzaeにおけるオートファジー によるオルガネラの分解

A）野生株（WT）ではペルオキシソーム (EGFP-PTS1)，ミトコンドリア（AoCit1EGFP)，核 (H2B-EGFP) の蛍光が液胞に 観察される. 一方，オートファジー欠損株 $(\Delta$ Aoatg 8$)$ では 48 時間後も液胞に蛍光は 観察されない. DIC：微分干涉像. B) 隔 離膜により核が取り囲まれる様子（上）. オートファゴソームによって囲まれた核が 液胞に入り分解される (下). 矢頭 : 液胞. 矢印：核.スケールバーは $5 \mu \mathrm{m}$. 文献 10 から改変して掲載.
EGFP-AoAtg8融合タンパク質で，核をマーカータンパ ク質ヒストンH2B-mDsRed融合タンパク質で可視化し 観察したところ，隔離膜が核の周縁部に沿って伸長し最 終的にオートファゴソームが核を丸ごと取り囲み, 液胞 に取り达まれ分解される様子が観察された ${ }^{(10)}$ (図2B). これまで, S. cerevisiaeに打いて核の一部をミクロオー トファジーで分解する piecemeal microautophagy of the nucleus (PMN) が報告されているが(13)，オート ファジーによる丸ごとの核の分解は, A. oryzaeで初め て発見された現象である。 その後, Magnaporthe oryzae の付着器形成時にオートファジー依存的に核が分解され ることが報告された ${ }^{(14)}$.これは, 多核細胞からなる糸 状菌では，栄養源の枯渴した条件下では核をも栄養源と して利用する“したたかさ”を示すものであり，A． oryzaeのような糸状菌がなぜ細胞に複数個の核をもつか という疑問に対する一つの答えになるのではないかと考 えられる。

\section{植物病原性糸状菌とオートファジー}

近年, オートファジーが糸状菌の植物への感染性にも 大きく関与していることが明らかとなってきた，病原性 糸状菌に打けるオートファジーについては, イネいもち
病の原因菌である $M$. oryzaeで研究が精力的に行われて いる. 分生子が宿主であるイネの葉面に接触すると発芽 管を伸ばし, その先端が付着器と呼ばれる構造に分化す る. その後, 付着器から侵入菌系を形成し, イネの細胞 内に侵入する. Moatg8破壊株では付着器は形成するも のの, その後の分生子の細胞死が行われず，侵入菌糸が 形成できず感染性を失うことが知られている ${ }^{(4)}$.また, 付着器からのイネ細胞への侵入は, 葉の表面に接触して いる付着器の強大な膨圧が必要とされる。この膨圧は, 付着器内の液胞にグリセロールなどが蓄積することで得 られていると考えられておりり ${ }^{(15)}$, Moatg5 破壊株などの オートファジー欠損株では, グリセロールが蓄積した液 胞が形成されず膨圧が獲得できないと報告されてい る $^{(15,16)}$.

ウリ類炭疽病菌Colletotrichum orbiculare の Coatg8 破壊株では正常な機能をもつ付着器形成が行えず，感染 能を失う ${ }^{(17)}$. また, ペキソファジー関連遺伝子 Coatg26の破壊株では, 付着器は形成されるがそれに続 く宿主への侵入ができなくなる ${ }^{(17)}$. 付着器のメラニン 化にはペルオキシソームによる脂肪酸の $\beta$ 酸化が関与し ており, ペルオキシソームは付着器機能の成熟に重要で あるが, 過剩のペルオキシソームは宿主細胞への侵入に 障害をもたらすと推測され, 付着器の形成から宿主細胞 
への侵入の各段階におけるペキソファジーによる厳密な ペルオキシソーム量の調節が重要であると考えられてい $ろ^{(17,18)}$.

以上のように, $M$. oryzaeをはじめとする植物病原性 糸状菌では, 正常な機能をもった付着器形成に必要な糖 代謝や脂質代謝にオートファジーが重要な機能を果たし ていることが明らかとなってきた．また，分生子が発芽 した菌糸が宿主植物に侵入するまでは, 栄養源が外界か ら獲得できないため，分生子を細胞死させその栄養源を リサイクルすることによって付着器形成ならびに侵入菌 糸の生長を行っているのではないかと考えられる.

動物に感染するA. fumigatusで, Afatg1破壊株のマ ウスを用いた感染実験が行われているが，感染能は正常 であったと報告されている ${ }^{(19)}$. 植物への感染と異なり, 動物細胞への感染では, 付着器の形成が必要ないためと 思われる。

\section{糸状菌オートファジーの有用物質生産への応用}

一般に A. oryzaeなどの糸状菌は菌系先端より多量の 酵素を分泌する能力を有しており, 異種タンパク質生産 の宿主として広く利用されている．筆者らは，A，oryzaeにおいて多量に分泌される $\alpha$-アミラーゼ AmyBのジ スルフィド結合を欠損した変異 $\mathrm{AmyB}$ を発現させ観察 したところ, 変異 AmyBがオートファジー依存的に液 胞へ輸送されることを見いだした ${ }^{(11)}$ 。そのため, オー トファジーによる分解も異種タンパク質生産のボトル ネックの一つではないかと考えた。そこで，A. oryzae のオートファジー関連遺伝子破壊株 (Aoatg1, Aoatg13, Aoatg4, Aoatg8）において, 異種タンパク質のウシキモ シンを発現させ，その生産性を検討した。その結果，コ ントロール株に比べて最大で3.1倍（Aoatg4破壊株）の 生産量の増加が見られた ${ }^{(20)}$ (図3)。なぜ，オートファ ジーが機能しないとウシキモシンの生産性が向上する か，現時点では詳細は不明であるが，少なくとも今回の 結果から，正しいフォールデイングができず小胞体内に 蓄積した異種タンパク質が，これまでプロテアソームで 分解されるとされていた経路（小胞体関連分解）以外 に,オートファジーによっても分解されることが示唆さ れた。

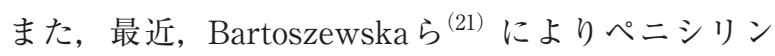
生産を増加させる方法としてPenicillium chrysogenum の atg1破壊株による生産が報告された. P. chrysogenumにおいて, $\beta$-ラクタム系抗生物質であるペニシリン は, 生合成経路のイソペニシリン $\mathrm{N}$ までは細胞質で合

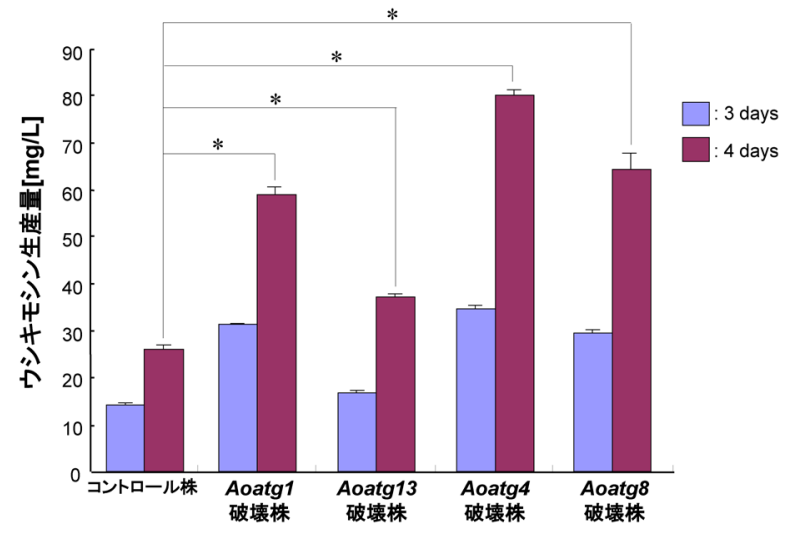

図 3 -A. oryzaeにおけるオートファジー関連遺伝子破壊株の ウシキモシン生産

コントロール株に比べAoatg1破壊株, Aoatg4破壊株, Aoatg8破 壞株で顕著な生産量増加が見られた。 * $p<0.05$ ( $t$ 検定)。文献 20 から改変して掲載.

成され，その後ペルオキシソームに局在するイソペニシ リンN-アシルトランスフェラーゼにより生合成が進み ペニシリンとなる ${ }^{(22,23)} . \operatorname{atg} 1$ 破壊株では, ペキソファ ジーによるペルオキシソーム分解が抑制され，結果とし てペニシリン生産性が向上したと考えられている.

糸状菌以外でも，生産性の向上に関して, Shiroma ら ${ }^{(24)}$ は, 最近, 日本酒の醸造中に清酒酵母でマイト ファジーが起こっていることを見いだし，マイトファ ジーが起こらない atg32破壊株ではエタノールの生産効 率が上がることを報告している。これまで，オートファ ジーは基礎的な細胞生物学の分野での研究が中心であっ た。しかし，上記の例のように，物質生産の場では，栄 養源枯渴は通常頻繁に起こりうる環境であり，このよう なときに起こるオートファジーを制御することは，さま ざまな物質生産の向上につながることを示唆していると 思われる。

\section{おわりに}

これまでオートファジーの研究は真核生物のモデル生 物である出芽酵母や，オートファジーの疾患への関与か ら哺乳動物で活発に行われてきた. 酵母は単細胞生物で あり，オートファジーの分子機構の解析には極めて有用 であるが，多細胞生物におけるオートファジーの生理機 能解明には限界がある。一方, 哺乳動物ではオートファ ジーの時間的, 空間的制御が複雑であり, 全体像を掴む ための実験系には制約がある。そのような意味で，われ われの生活に密接にかかわり，多細胞でさまざまな性質 を有する系状菌による研究はオートファジーの全体像を 
つかむうえでも重要な意味をもつと考えられる。また， 糸状菌オートファジーの研究は病原性系状菌に対する薬 凨の開発，食品製造，有用物質生産といった応用におい ても重要であると考えられ，今後さらなる研究の進展が 期待される.

\section{文献}

1) B. Pinan-Lucarré, M. Paoletti, K. Dementhon, B. CoularySalin \& C. Clavé: Mol. Microbiol., 47, 321 (2003).

2) B. Pinan-Lucarré, A. Balguerie \& C. Clavé: Eukaryot. Cell, 4, 1765 (2005).

3) T. Kikuma, M. Ohneda, M. Arioka \& K. Kitamoto: Eukaryot. Cell, 5, 1328 (2006).

4) C. Veneault-Fourrey, M. Barooah, M. Egan, G. Wakley \& N. J. Talbot: Science, 312, 580 (2006).

5) T. Kikuma \& K. Kitamoto: FEMS Microbiol. Lett., 316, 61 (2011)

6) S. Yanagisawa, T. Kikuma \& K. Kitamoto: FEMS Microbiol. Lett., 338, 168 (2013).

7) T. Kikuma, M. Arioka \& K. Kitamoto: Autophagy, 3, 128 (2007).

8) Y. Mabashi, T. Kikuma, J. Maruyama, M. Arioka \& K. Kitamoto: Biosci. Biotechnol. Biochem., 70, 1882 (2006).

9) J. Maruyama, S. Kikuchi \& K. Kitamoto: Fungal Genet. Biol., 43, 642 (2006).

10) J. Y. Shoji, T. Kikuma, M. Arioka \& K. Kitamoto: PLoS ONE, 5, e15650 (2010).

11) S. Kimura, J. Maruyama, T. Kikuma, M. Arioka \& K. Kitamoto: Biochem. Biophys. Res. Commun., 406, 464 (2011).

12) J. Y. Shoji, M. Arioka \& K. Kitamoto: Autophagy, 2, 226 (2006).

13) E. Kvam \& D. S. Goldfarb: Autophagy, 3, 85 (2007).

14) M. He, M. J. Kershaw, D. M. Soanes, Y. Xia \& N. J. Talbot: PLoS ONE, 7, e33270 (2012).

15) X. H. Liu, H. M. Gao, F. Xu, J. P. Lu, R. J. Devenish \& F. C. Lin: Autophagy, 8, 1415 (2012).

16) X. H. Liu, J. P. Lu \& F. C. Lin: Autophagy, 3, 472 (2007).

17) M. Asakura, S. Ninomiya, M. Sugimoto, M. Oku, S. Yamashita, T. Okuno, Y. Sakai \& Y. Takano: Plant Cell, 21, 1291 (2009).

18) Y. Takano, M. Asakura \& Y. Sakai: Autophagy, 5, 1041 (2009).

19) D. L. Richie, K. K. Fuller, J. Fortwendel, M. D. Miley, J. W. McCarthy, M. Feldmesser, J. C. Rhodes \& D. S. Askew: Eukaryot. Cell, 6, 2437 (2007).

20) J. Yoon, T. Kikuma, J. Maruyama \& K. Kitamoto: PLoS ONE, 8, e62512 (2013).

21) M. Bartoszewska, J. A. Kiel, R. A. Bovenberg, M. Veenhuis \& I. J. van der Klei: Appl. Environ. Microbiol., 77, $1413(2011)$

22) W. H. Meijer, L. Gidijala, S. Fekken, J. A. Kiel, M. A. van den Berg, R. Lascaris, R. A. Bovenberg \& I. J. van der Klei: Appl. Environ. Microbiol., 76, 5702 (2010).

23) J. F. Martín, R. V. Ullán \& C. García-Estrada: J. Ind. Microbiol. Biotechnol., 39, 367 (2012).

24) S. Shiroma, L. N. Jayakody, K. Horie, K. Okamoto \& H. Kitagaki: Appl. Environ. Microbiol., 80, 1002 (2014).

25) M. J. Kershaw \& N. J. Talbot: Proc. Natl. Acad. Sci. USA, 106, 15967 (2009).

26) X. H. Liu, J. P. Lu, L. Zhang, B. Dong, H. Min \& F. C. Lin: Eukaryot. Cell, 6, 997 (2007).

27) G. Park, J. A. Servin, G. E. Turner, L. Altamirano, H. V.
Colot, P. Collopy, L. Litvinkova, L. Li, C. A. Jones, F. G. Diala et al:: Eukaryot. Cell, 10, 1553 (2011).

28) Z. Duan, Y. Chen, W. Huang, Y. Shang, P. Chen \& C. Wang: Autophagy, 9, 538 (2013).

29) B. M. Nitsche, A. M. Burggraaf-van Welzen, G. Lamers, V. Meyer \& A. F. Ram: Appl. Microbiol. Biotechnol., 97, 8205 (2013).

30) B. Dong, X. H. Liu, J. P. Lu, F. S. Zhang, H. M. Gao, H. K. Wang \& F. C. Lin: Autophagy, 5, 946 (2009).

31) T. B. Liu, X. H. Liu, J. P. Lu, L. Zhang, H. Min \& F. C. Lin: Autophagy, 6, 74 (2010).

32) O. Voigt \& S. Pöggeler: Autophagy, 9, 33 (2013).

33) J. P. Lu, X. H. Liu, X. X. Feng, H. Min \& F. C. Lin: Curr. Genet., 55, 461 (2009).

34) X. H. Liu, J. Yang, R. L. He, J. P. Lu, C. L. Zhang, S. L. Lu \& F. C. Lin: Res. Microbiol., 162, 756 (2011).

35) L. Zhang, J. Wang, X. Q. Xie, N. O. Keyhani, M. G. Feng \& S. H. Ying: Microbiology, 159, 243 (2013).

36) N. Nolting, Y. Bernhards \& S. Pöggeler: Fungal Genet. Biol., 46, 531 (2009).

37) Y. Z. Deng, M. Ramos-Pamplona \& N. I. Naqvi: Autophagy, 5, 33 (2009).

38) L. Josefsen, A. Droce, T. E. Sondergaard, J. L. Sørensen, J. Bormann, W. Schäfer, H. Giese \& S. Olsson: Autophagy, 8, 326 (2012).

39) Y. L. Chen, Y. Gao, K. Q. Zhang \& C. G. Zou: Environ. Microbiol. Rep., 5, 511 (2013).

40) L. N. Nguyen, J. Bormann, G. T. Le, C. Stärkel, S. Olsson, J. D. Nosanchuk, H. Giese \& W. Schäfer: Fungal Genet. Biol., 48, 217 (2011).

41) Y. He, Y. Z. Deng \& N. I. Naqvi: Autophagy, 9, 1818 (2013)
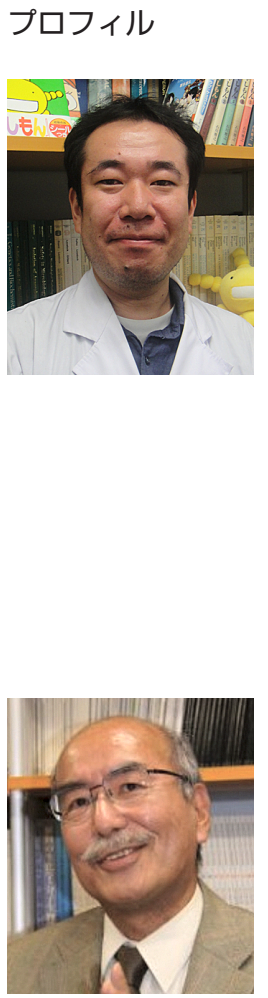

菊間 隆志 (Takashi KIKUMA)

<略歴 $>2001$ 年東京理科大学基礎工学部 生物工学科卒業 $/ 2003$ 年同大学大学院基 礎工学研究科生物工学専攻修士課程修了／ 2007 年東京大学大学院農学生命科学研究 科応用生命工学専攻博士課程修了, 博士 (農学)／同年シアトルでバイオベンチャー 立上げに従事 $/ 2008$ 年東京大学大学院農 学生命科学研究科特任研究員/2009年理 化学研究所特別研究員 / 2011年東京大学 大学院農学生命科学研究科応用生命工学専 攻特任助教, 現在に至る<研究テーマと抱 負>趜菌におけるオートファジーの解析を 通して糸状菌特異的機能および普遍的なメ カニズムを解明するく趣味＞美酒（生酛純 米酒，手工芸麦酒など)，美食（唐墨，鮟 肝, 寒造里など), 登山（活火山は除く）

北本 勝ひこ (Katsuhiko KITAMOTO) $<$ 略歴 $>1972$ 年東京大学農学部農芸化学 科卒業/同年国税庁醸造試験所研究員/ 1988年同主任研究員 / 1995年東京大学農 学部助教授 $/ 1996$ 年同大学大学院農学生 命科学研究科教授, 現在に至る<研究テー マと抱負>美味しい日本酒を造るキープレ イヤー, 敖菌について細胞生物学的に理解 すること，ならびに伝統的酒造りに扮ける 杜氏の秘伝を分子生物学的に解明すること <趣味>バードウオッチング, 蝶の食草栽 培，俳句，短歌，塩鍻つくり

Copyright （） 2014 公益社団法人日本農芸化学会 